\title{
Irvine-Gass Syndrome
}

\author{
Weni Helvinda, Elfi Risalma Puteri
}

Abstrak

CME merupakan penebalan retina lokal dimana cairan terakumulasi dalam ruang kistik pada lapisan luar retina di makula. Irvine Gass Syndrome merupakan CME yang terjadi setelah operasi katarak yang ditandai dengan cystoid multipel pada makula. Tujuan: Untuk melaporkan kasus Irvine Gass Syndrome. Hasil: Laki-laki 60 tahun dengan visus mata kanan 5/60, IOL pada posterior chamber dengan PCO. Pada funduskopi terdapat edema makula. OCT ditemukan CME. Pada pasien dilakukan ECCE 4 bulan sebelumnya. Pseudofakic CME dapat muncul paling cepat 3 minggu dan paling lambat 6 bulan setelah operasi. CME didefinisikan jika visus 20/40 atau lebih buruk disertai ruang cystoid. OCT menunjukkan hyporeflektif di dalam retina, dengan penebalan makula. Perubahan ketebalan makula $\geq 40 \mu \mathrm{m}$ merupakan indeks OCT significant macular edema. Pasien diberikan NSAIDs topikal yang menghambat cyclooxygenase yang berperan dalam biosintesa prostaglandin karena patogenesa Irvine Gass syndrome disebabkan oleh inflamasi. Setelah itu visus membaik dan pada OCT terdapat pengurangan ketebalan makula. Pasien juga diberikan Carbonic anhidrase inhibitor oral yang menstimulasi pompa RPE untuk mengurangi cairan di macula. Kesimpulan: Pada Kasus ini Pseudofakic CME terjadi 12 minggu setelah operasi katarak. Terdapat respon terapi yang baik dengan NSAIDs topikal, kortikosteroid oral dan Carbonic Anhidrase Inhibitor.

Kata kunci: Pseudofakic CME, Irvine Gass Syndrome, CME, NSAIDs topikal, kortikosteroid oral dan Carbonic Anhidrase Inhibitor

\begin{abstract}
Introduction: CME is a localized thickened of the retina where there was an accumulation of fluid within cyst at the retinal outer layer of macula. Irvine Gass Syndrome is a type of CME typically with multiple cystoid form of macula which formed after cataract surgery Aim : presentation a case report of Irvine gass Syndrome. Report: a 60 man years old presenting with right visual acuity 5/60, IOL at posterior chamber with PCO. By funduscopy examination, found that there was a macular oedem. OCT found CME. The patient had performed ECCE 4 month ago. Pseudophakic CME could occured ranging from 3 weeks to 6 month after surgery. CME defined as visual acuity < 20/40 followed with cyst. OCT examination found hyporeflection of the retina, and also thickened of macula. Thickened of macula $\geq 40 \mu \mathrm{m}$ from OCT examination reflect a significant of macular oedem. The patient then treated with topical NSAID with aim to inhibit cyclooxygenase which is important in prostaglandin synthesis that is vital in inflammation procces. There was an improvement of vsual acuity after treatment and OCT examination found a reduction of macular thickness. Patient also treated with Carbonic anhidrase inhibitor peroral which could stimulate RPE pumping mechanism so could reduce the fluid of macula conclusion: in this case report, pseudiphakic CME develop 12 weeks after cataract surgery. There was favourable respons of therapy with topical NSAID, oral corticosteroids and Carbonic Anhidrase Inhibitor.
\end{abstract}

Keywords: Pseudofakic CME, Irvine Gass Syndrome, CME, topical NSAIDs, oral corticosteroid and Carbonic Anhidrase Inhibitor

Affiliasi penulis : Weni helvinda

Korespondensi :Weni Helvinda helvindawenispm@gmail.com Telp: [Company Phone]

\section{Pendahuluan}

Edema makula merupakan kondisi yang terjadi akibat adanya akumulasi cairan di dalam ruang subretina atau diantara beberapa lapis jaringan retina yang disebabkan oleh faktor mekanis maupun faktor kimia. Edema makula dapat menyebabkan penebalan retina yang terjadi difus maupun lokal. Cystoid Macular Edema (CME) merupakan bentuk penebalan retina yang terjadi lokal dimana cairan terakumulasi dalam bentuk ruang kistik terutama pada lapisan luar retina pada makula. ${ }^{1}$
CME merupakan konsekuensi dari gangguan blood-retinal barrier yang terjadi sekunder terhadap berbagai kondisi patologis yang mendasarinya. .,2 $^{1,2}$ Kondisi patologis yang mendasari terjadinya CME diantaranya terjadi akibat kondisi lokal okular seperti epiretinal membran dan neovaskularisasi subretina, akibat penyakit okular dan penyakit vaskular sistemik, seperti pada retinopati diabetik, retinopati hipertensi , oklusi vena retina, neovaskularisasi koroid, serta akibat inflamasi intraokular seperti pada uveitis dan

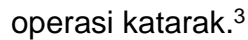

CME sampai saat ini masih merupakan salah satu penyebab terbanyak kasus penurunan visus setelah operasi katarak. CME yang terjadi setelah operasi katarak pertama kali dilaporkan oleh Irvine pada tahun 1953 dan secara angiografi pertama kali 
dikemukakan oleh Gass dan Norton pada tahun 1966, sehingga saat ini dikenal sebagai Irvine-Gass Syndrome. . $^{4}$

Irvine Gass Syndrome merupakan CME yang terjadi setelah operasi katarak yang ditandai dengan area cystoid (cyst-like) multipel pada daerah makula. Insiden CME diperkirakan 50\% setelah Intracapsular Cataract Extraction (ICCE), 20\% setelah Extracapsular Cataract Extraction (ECCE) dan 19\% setelah fakoemulsifikasi. Pada umumnya terjadi 6-8 minggu setelah operasi. 6,7

Faktor resiko terjadinya CME post operatif diantaranya kehilangan vitreus intraoperatif, penempatan Intra Ocular Lens (IOL) pada kamera okuli anterior (KOA), inflamasi post operatif yang lama. Diagnosis ditegakkan berdasarkan gejala klinis yang ditemukan, pemeriksaan Fundus Fluorescein Angiography (FFA), dan Optical Coherence Tomography OCT).$^{5}$

\section{Laporan Kasus}

Seorang pasien laki-laki, umur 60 tahun, datang ke RS M. Djamil Padang pada tanggal 13 Januari 2014 , dengan keluhan utama mata kanan terasa lebih kabur sejak \pm 1 bulan yang lalu. Mata kanan juga terasa kabur sejak 1 tahun yang lalu dan pada tanggal 9 September 2013, mata kanan pasien telah dilakukan operasi katarak dengan pemasangan IOL. Setelah dilakukan operasi, penglihatan pasien membaik dam kabur kembali sejak 1 bulan ini. Mata kiri pasien sudah tidak dapat melihat lagi sejak \pm 5 tahun ini. Mata kiri pasien tidak dapat melihat lagi sejak \pm 5 tahun yang lalu, kontrol poli mata tidak teratur dan didiagnosa dengan glaukoma absolut. Riwayat operasi katarak mata kiri 7 tahun yang lalu. Riwayat Diabetes Mellitus disangkal Riwayat Hipertensi disangkal Riwayat Mata kanan merah dan disertai rasa sakit disangkal

\section{STATUS OFTALMOLOGI}

\begin{tabular}{|c|c|c|}
\hline $\begin{array}{c}\text { Status } \\
\text { Oftalmologi }\end{array}$ & OD & OS \\
\hline Visus & $5 / 60$ & 0 \\
\hline Refleks fundus & $(+)$ & $(-)$ \\
\hline Supersilia/Silia & $\begin{array}{c}\text { Dalam } \\
\text { batas } \\
\text { normal }\end{array}$ & $\begin{array}{c}\text { Dalam batas } \\
\text { normal }\end{array}$ \\
\hline Palpebra & Edema (-) & Edema (-) \\
\hline Aparat Lakrimalis & $\begin{array}{l}\text { Dalam } \\
\text { batas } \\
\text { normal }\end{array}$ & $\begin{array}{c}\text { Dalam batas } \\
\text { normal }\end{array}$ \\
\hline Konyungtiva & $\begin{array}{c}\text { Hiperemis } \\
(-)\end{array}$ & Hiperemis (-) \\
\hline Sklera & putih & putih \\
\hline Kornea & bening & $\begin{array}{c}\text { Keratopati (+), } \\
\text { Neovaskularisasi } \\
(+)\end{array}$ \\
\hline $\begin{array}{ll}\text { Camera } & \text { Oculi } \\
\text { Anterior } & \end{array}$ & $\begin{array}{l}\text { Cukup } \\
\text { dalam , } \\
\text { VH3 }\end{array}$ & Cukup dalam VH3 \\
\hline Iris & $\begin{array}{l}\text { Coklat, } \\
\text { rugae }(+)\end{array}$ & $\begin{array}{c}\text { Membayang } \\
\text { coklat, } \\
\text { neovaskularisasi } \\
(+)\end{array}$ \\
\hline Pupil & Bulat rf $+/-$ & $\begin{array}{l}\text { Membayang bulat, } \\
\text { rf -/- }\end{array}$ \\
\hline Lensa & $\begin{array}{l}\text { IOL }(\mathrm{pc}) \\
\mathrm{PCO}(+)\end{array}$ & Sulit dinilai \\
\hline
\end{tabular}

\begin{tabular}{|c|c|c|}
\hline Corpus Vitreus & Jernih & Sulit dinilai \\
\hline \multicolumn{3}{|l|}{ Funduskopi } \\
\hline \multirow{2}{*}{$\begin{array}{l}\text { Media } \\
\text { Papil } \\
\text { Pembuluh darah }\end{array}$} & $\begin{array}{l}\text { Relatif } \\
\text { bening }\end{array}$ & keruh \\
\hline & $\begin{array}{c}\text { Bulat, batas } \\
\text { tegas } \mathrm{c} / \mathrm{d} \\
0.3-0.4\end{array}$ & Sulit dinilai \\
\hline Pembuluh darah & $\begin{array}{c}\text { Aa: } V v= \\
2: 3\end{array}$ & Sulit dinilai \\
\hline Retina & $\begin{array}{c}\text { Perdarahan } \\
(-) \text {, eksudat } \\
(-)\end{array}$ & Sulit dinilai \\
\hline Makula & $\begin{array}{c}\text { Refleks } \\
\text { fovea }(+) \downarrow \\
\text { edema } \\
\text { makula }(+) \\
\end{array}$ & Sulit dinilai \\
\hline $\begin{array}{ll}\text { Tekanan } & \text { Intra } \\
\text { Okular } & \\
\end{array}$ & $\begin{array}{c}4 / 5.5 \infty 20.6 \\
\mathrm{mmHg}\end{array}$ & $\begin{array}{c}0 / 5.5 \infty 0 / 7.5 \infty 2 / 10 \\
\infty 59 \mathrm{mmHg}\end{array}$ \\
\hline Posisi & Ortho & ortho \\
\hline Gerak & Bebas & bebas \\
\hline
\end{tabular}

Pemeriksaan Penunjang:

OCT:

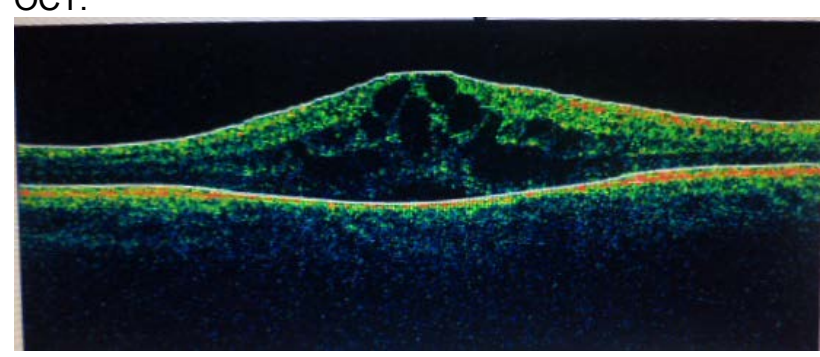

Kesan : Cystoid Macular Edema Diagnosis : Ketebalan retina $769 \mu \mathrm{m}$

- Cystoid Macular Edema OD

- Pseudofakia + Posterior Capsular Opacification OD

- Glaukoma Absolut OS

Terapi :

- Noncort eye drop 4x1 OD

- Glaucon 3x1 tablet

- $\quad$ Aspar K 2x1 tablet

- Timol 0.5\% 2x1 OS

Follow up 30 Januari 2013 (Minggu ke-2)

Anamnesis : penglihatan mata kanan sudah mulai membaik

\section{STATUS OFTALMOLOGI}

\begin{tabular}{|c|c|c|}
\hline $\begin{array}{l}\text { STATUS } \\
\text { OFTALMOLO } \\
\text { GI }\end{array}$ & OD & OS \\
\hline Visus & $\begin{array}{c}5 / 15 \text { cc S- } \\
1 \text { C- } \\
0.75\left(90^{\circ}\right) \\
\rightarrow 5 / 6\end{array}$ & 0 \\
\hline Refleks fundus & $(+)$ & $(-)$ \\
\hline Supersilia/Silia & $\begin{array}{c}\text { Dalam } \\
\text { batas } \\
\text { normal }\end{array}$ & \multirow{6}{*}{ Status quo } \\
\hline Palpebra & Edema (-) & \\
\hline $\begin{array}{l}\text { Aparat } \\
\text { Lakrimalis }\end{array}$ & $\begin{array}{c}\text { Dalam } \\
\text { batas } \\
\text { normal }\end{array}$ & \\
\hline Konyungtiva & $\begin{array}{c}\text { Hiperemis } \\
(-)\end{array}$ & \\
\hline Sklera & putih & \\
\hline Kornea & bening & \\
\hline
\end{tabular}




\begin{tabular}{|c|c|c|}
\hline $\begin{array}{l}\text { Camera Oculi } \\
\text { Anterior }\end{array}$ & $\begin{array}{l}\text { Cukup } \\
\text { dalam , } \\
\text { VH3 }\end{array}$ & \\
\hline Iris & $\begin{array}{l}\text { Coklat, } \\
\text { rugae }(+)\end{array}$ & \\
\hline Pupil & Bulat if $+/-$ & \\
\hline Lensa & $\begin{array}{l}\text { IOL (pc) } \\
\text { PCO (+) }\end{array}$ & \\
\hline Corpus Vitreus & Jernih & \\
\hline Funduskopi & & \\
\hline Media & $\begin{array}{l}\text { Relatif } \\
\text { bening }\end{array}$ & \\
\hline Papil & $\begin{array}{c}\text { Bulat, } \\
\text { batas } \\
\text { tegas c/d } \\
0.3-0.4\end{array}$ & \\
\hline $\begin{array}{l}\text { Pembuluh } \\
\text { darah }\end{array}$ & $\begin{array}{c}\text { Aa: } V v= \\
2: 3\end{array}$ & \\
\hline Retina & $\begin{array}{l}\text { Perdaraha } \\
\text { n (-), } \\
\text { eksudat (-) }\end{array}$ & \\
\hline Makula & $\begin{array}{c}\text { Refleks } \\
\text { fovea }(+) \text {, } \\
\text { edema } \downarrow\end{array}$ & \\
\hline $\begin{array}{l}\text { Tekanan Intra } \\
\text { Okular }\end{array}$ & $\begin{array}{c}5 / 5.5 \infty \\
17.3 \\
\mathrm{mmHg}\end{array}$ & $\begin{array}{c}0 / 5.5 \infty 0 / 7.5 \infty 4 / 10 \\
\infty 43.3 \mathrm{mmHg}\end{array}$ \\
\hline Posisi & Ortho & ortho \\
\hline Gerak & Bebas & bebas \\
\hline
\end{tabular}

Pemeriksaan Penunjang: OCT

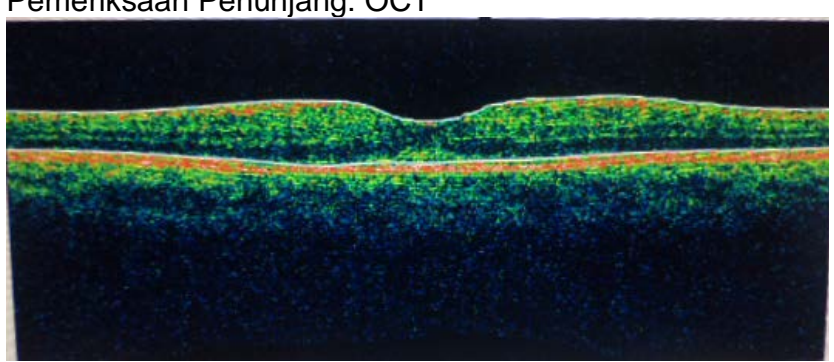

Kesan : Edema retina dalam perbaikan Ketebalan retina $220 \mu \mathrm{m}$

Diagnosis :

- Cystoid Macular Edema OD dalam perbaikan

- Pseudofakia + Posterior Capsular Opacification OD

- Glaukoma Absolut OS

Terapi : dilanjutkan

Follow up Tanggal 19 Februari 2014 (Minggu ke-5) Anamnesis : Penglihatan mata kanan sudah membaik STATUS OFTALMOLOGI

\begin{tabular}{|c|c|c|}
\hline $\begin{array}{l}\text { STATUS } \\
\text { OFTALMOLOG } \\
\text { a }\end{array}$ & OD & OS \\
\hline Visus & $\begin{array}{c}5 / 15 \text { S-1 } \\
\text { C-0.75 } \\
\left(90^{\circ}\right) \rightarrow \\
5 / 6\end{array}$ & 0 \\
\hline Refleks fundus & $(+)$ & $(-)$ \\
\hline Supersilia/Silia & \multirow{7}{*}{ Status quo } & \multirow{7}{*}{ Status quo } \\
\hline Palpebra & & \\
\hline $\begin{array}{l}\text { Aparat } \\
\text { Lakrimalis }\end{array}$ & & \\
\hline Konyungtiva & & \\
\hline Sklera & & \\
\hline Kornea & & \\
\hline Camera Oculi & & \\
\hline
\end{tabular}

\begin{tabular}{|c|c|c|}
\hline Anterior & & \\
\hline Iris & & \\
\hline Pupil & & \\
\hline Lensa & & \\
\hline Corpus Vitreus & & \\
\hline $\begin{array}{l}\text { Funduskopi } \\
\text { Media } \\
\text { Papil } \\
\text { Pembuluh } \\
\text { darah } \\
\text { Retina } \\
\text { Makula }\end{array}$ & $\begin{array}{l}\text { Dalam } \\
\text { batas } \\
\text { Normal }\end{array}$ & \\
\hline $\begin{array}{l}\text { Tekanan Intra } \\
\text { Okular }\end{array}$ & $\begin{array}{c}4 / 5.5 \\
\infty 20.6 \\
\mathrm{mmHg}\end{array}$ & $\begin{array}{c}0 / 5.5 \infty 0 / 7.5 \infty 2 / 1 \\
0 \propto 59 \mathrm{mmHg}\end{array}$ \\
\hline Posisi & Ortho & ortho \\
\hline Gerak & Bebas & bebas \\
\hline
\end{tabular}

Pemeriksaan Penunjang: OCT

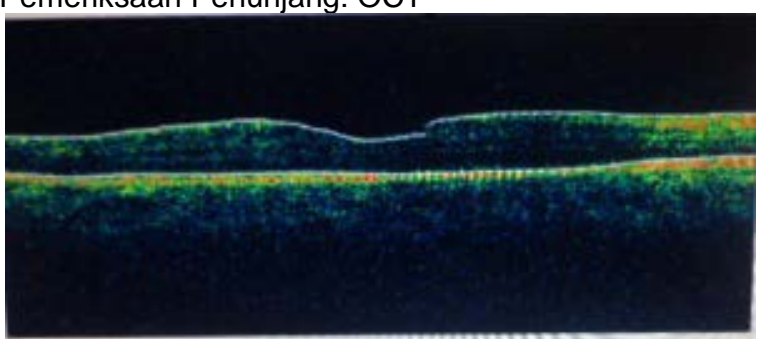

Kesan : Edema makula dalam perbaikan Ketebalan retina $238 \mu \mathrm{m}$

Diagnosis :

- Cystoid Macular Edema OD

- Pseudofakia + Posterior Capsular Opacification OD

- Glaukoma Absolut OS

Terapi :

- Noncort eye drop 4x1 OD

- $\quad$ Glaucon 3x1 tablet $\rightarrow$ stop

- $\quad$ Aspar K 2X1 tablet $\rightarrow$ stop

- Timol 0.5\% 2x1 OS

Follow up Tanggal 25 Februari 2014 (Minggu ke-6) Anamnesis : Penglihatan Mata kanan dirasakan kembali kabur

\begin{tabular}{|c|c|c|}
\hline $\begin{array}{l}\text { STATUS } \\
\text { OFTALMOLOGI }\end{array}$ & OD & OS \\
\hline Visus & $\underset{(-)}{5 / 20} \rightarrow$ ph & 0 \\
\hline Refleks fundus & $(+)$ & $(-)$ \\
\hline Supersilia/Silia & $\begin{array}{c}\text { Dalam } \\
\text { batas } \\
\text { normal }\end{array}$ & \multirow{11}{*}{ Status quo } \\
\hline Palpebra & Edema (-) & \\
\hline $\begin{array}{l}\text { Aparat } \\
\text { Lakrimalis }\end{array}$ & $\begin{array}{c}\text { Dalam } \\
\text { batas } \\
\text { normal }\end{array}$ & \\
\hline Konyungtiva & $\begin{array}{c}\text { Hiperemis } \\
(-)\end{array}$ & \\
\hline Sklera & putih & \\
\hline Kornea & bening & \\
\hline $\begin{array}{l}\text { Camera Oculi } \\
\text { Anterior }\end{array}$ & $\begin{array}{l}\text { Cukup } \\
\text { dalam , } \\
\text { VH3 }\end{array}$ & \\
\hline Iris & $\begin{array}{l}\text { Coklat, } \\
\text { rugae }(+)\end{array}$ & \\
\hline Pupil & Bulat if $+/-$ & \\
\hline Lensa & $\begin{array}{l}\mathrm{IOL}(\mathrm{pc}) \\
\mathrm{PCO}(+)\end{array}$ & \\
\hline Corpus Vitreus & Jernih & \\
\hline
\end{tabular}




\begin{tabular}{|c|c|c|}
\hline \multirow[t]{2}{*}{ Funduskopi } & & \\
\hline & $\begin{array}{l}\text { Relatif } \\
\text { bening }\end{array}$ & \\
\hline Papil & $\begin{array}{c}\text { Bulat, batas } \\
\text { tegas c/d } \\
0.3-0.4\end{array}$ & \\
\hline Pembuluh darah & $\begin{array}{c}\text { Aa: } V v= \\
2: 3\end{array}$ & \\
\hline Retina & $\begin{array}{c}\text { Perdarahan } \\
(-) \text {, eksudat } \\
(-)\end{array}$ & \\
\hline Makula & $\begin{array}{c}\text { Refleks } \\
\text { fovea }(+) \downarrow \text {, } \\
\text { edema } \\
\text { makula }(+)\end{array}$ & \\
\hline $\begin{array}{l}\text { Tekanan Intra } \\
\text { Okular }\end{array}$ & $\begin{array}{c}5 / 5.5 \propto 17.3 \\
\mathrm{mmHg}\end{array}$ & $\begin{array}{l}0 / 5.5 \infty 0 / 7.5 \infty 4 / 10 \\
=43.3 \mathrm{mmHg}\end{array}$ \\
\hline Posisi & Ortho & ortho \\
\hline Gerak & Bebas & bebas \\
\hline
\end{tabular}

Pemeriksaan Penunjang: OCT

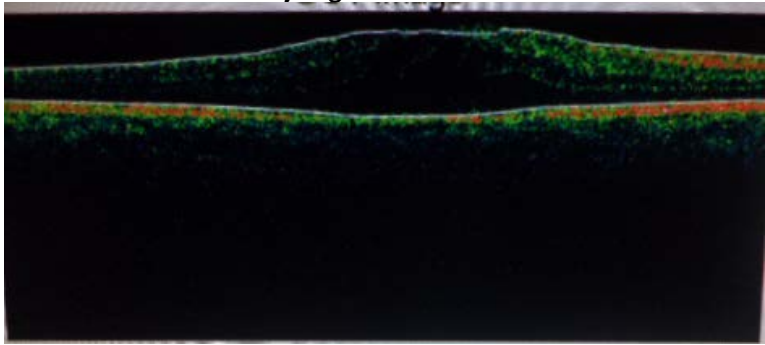

Kesan : Cystoid Macular Edema Ketebalan retina $507 \mu \mathrm{m}$

Diagnosis :

- $\quad$ Cystoid Macular Edema OD

- Pseudofakia + Posterior Capsular Opacification OD

- Glaukoma Absolut OS

Terapi :

- Noncort eye drop 4X1 OD $\rightarrow$ stop

- Glaucon 3x1 tablet

- $\quad$ Aspar K 2x1 tablet

- $\quad$ Timol 0.5\% 2x1 OS

- $\quad$ Methyl Prednisolon 1x32 mg

Follow up Tanggal 11 Maret 2014 (Minggu ke-8) Anamnesis : penglihatan mata kanan sudah mulai membaik

\begin{tabular}{|c|c|c|}
\hline $\begin{array}{l}\text { STATUS } \\
\text { OFTALMOLOG } \\
\text { I }\end{array}$ & OD & OS \\
\hline Visus & $\begin{array}{c}5 / 15 \text { S-1 } \\
\text { C-0.75 } \\
\left(90^{\circ}\right) \rightarrow \\
5 / 6 \\
\end{array}$ & 0 \\
\hline Refleks fundus & $(+)$ & $(-)$ \\
\hline $\begin{array}{l}\text { Supersilia/Silia } \\
\text { Palpebra }\end{array}$ & \multirow{10}{*}{ Status quo } & \multirow{10}{*}{ Status quo } \\
\hline $\begin{array}{l}\text { Aparat } \\
\text { Lakrimalis }\end{array}$ & & \\
\hline Konyungtiva & & \\
\hline Sklera & & \\
\hline Kornea & & \\
\hline $\begin{array}{l}\text { Camera Oculi } \\
\text { Anterior }\end{array}$ & & \\
\hline Iris & & \\
\hline Pupil & & \\
\hline Lensa & & \\
\hline Corpus Vitreus & & \\
\hline
\end{tabular}

\begin{tabular}{|c|c|c|}
\hline \multirow{2}{*}{$\begin{array}{l}\text { Funduskopi } \\
\text { Media }\end{array}$} & & \\
\hline & $\begin{array}{l}\text { Relatif } \\
\text { bening }\end{array}$ & \\
\hline \multirow{2}{*}{$\begin{array}{l}\text { Papil } \\
\text { Pembuluh } \\
\text { darah }\end{array}$} & $\begin{array}{c}\text { Bulat, } \\
\text { batas } \\
\text { tegas c/d } \\
0.3-0.4\end{array}$ & \\
\hline & $\begin{array}{c}\text { Aa: } V v= \\
2: 3\end{array}$ & \\
\hline Retina & $\begin{array}{c}\text { Perdaraha } \\
\text { n (-), } \\
\text { eksudat (-) }\end{array}$ & \\
\hline Makula & $\begin{array}{c}\text { Refleks } \\
\text { fovea }(+), \\
\text { edema } \\
\text { makula }(-)\end{array}$ & \\
\hline $\begin{array}{l}\text { Tekanan Intra } \\
\text { Okular }\end{array}$ & $\begin{array}{l}4 / 5.5 \\
\infty 20.6 \\
\mathrm{mmHg}\end{array}$ & $\begin{array}{c}0 / 5.5 \infty 0 / 7.5 \infty 2 / 1 \\
0 \propto 59 \mathrm{mmHg}\end{array}$ \\
\hline Posisi & Ortho & ortho \\
\hline Gerak & Bebas & bebas \\
\hline
\end{tabular}

Pemeriksaan Penunjang: OCT

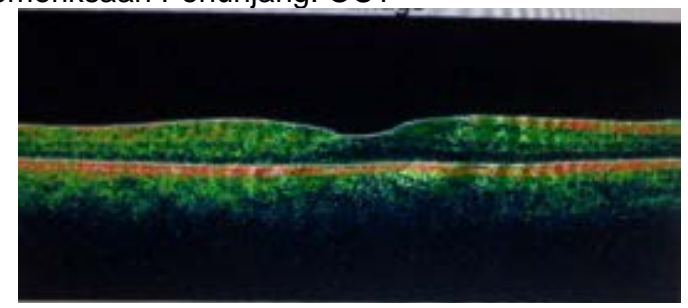

Kesan : Edema makula dalam perbaikan Ketebalan retina $232 \mu \mathrm{m}$

Diagnosis :

- Cystoid Macular Edema OD dalam perbaikan

- Pseudofakia + Posterior Capsular Opacification OD

- Glaukoma Absolut OS

Terapi:

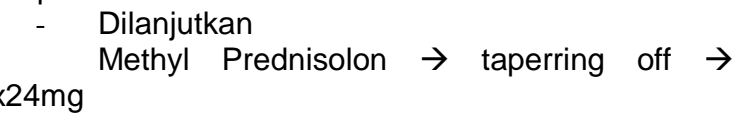

\section{DISKUSI}

Dilaporkan kasus Irvine-gass Syndrome atau Pseudofakic CME pada pasien laki-laki usia 60 tahun. Berdasarkan anamnesa didapatkan bahwa penglihatan mata kanan menurun setelah 4 bulan operasi katarak. Berdasarkan pemeriksaan visus pada saat diagnosis pada mata kanan adalah 5/60, Tekanan Intra Okular $20,6 \mathrm{mmHg}$, pemeriksaan segmen anterior mata kanan ditemukan adanya Intra Okular Lens (IOL) pada postrior chamber, dengan adanya Posterior Capsular Opacity (PCO). Pada funduskopi reflek fovea menurun dan ditemukan edema pada makula. Pemeriksaan OCT pada pasien ini ditemukan Cystoid Macular Edema dengan penebalan retina $769 \mu \mathrm{m}$.

Pada pasien ini dilakukan ECCE dan implantasi IOL 4 bulan sebelum terjadinya CME. Pada hari pertama post operasi visus menjadi $5 / 7 \mathrm{f}$ dan 4 bulan kemudian terjadi penurunan visus sampai 5/60. CME merupakan penyebab kehilangan visus yang sering terjadi setelah operasi katarak. Kent dkk pada tahun 2000 mengungkapkan bahwa Pseudofakic CME berkembang setelah ECCE kira-kira 20\% -30\% dan sering terjadi setelah $6-8$ minggu post operasi. ${ }^{8}$ Penelitian yang dilakukan oleh Ray dan Amico tahun 2000 menunjukkan CME yang terjadi setelah Intra 
Capsular Cataract Extraction (ICCE) rata-rata 50\%$70 \%$ sedangkan setelah ECCE dilaporkan 16\%-40\%. Saat ini dengan berkembangnya fakoemulsifikasi dengan menggunakan insisi yang minimal, teknik ini menjadi pilihan utama bagi operator karena lebih efisisen dengan keberhasilan visus yang baik. Namun demikian, masih dilaporkan adanya kasus Irvine-Gass Syndrome setelah fakoemulsifikasi. Ursell dkk tahun 1999 melaporkan 19\% kasus CME setelah fakoemulsifikasi,sedangkan Heier melaporkan variasi Irvine-Gass Syndrome antara 2\% - 12\%. 1,4,9

Onset terjadinya Irvine-Gass Syndrome pada kasus ini diduga 16 minggu setelah operasi. Menurut Walter, pasien dengan Irvine-Gass Syndrome datang dengan keluhan mata kabur 4-6 minggu setelah operasi katarak. Meskipun demikian gejala dapat muncul lebih awal kira-kira 2 minggu setelah operasi atau bahkan lebih lambat yakni 12 minggu setelah operasi katarak. ${ }^{8}$ Scheufele melaporkan, Pseudofakic CME dapat muncul paling cepat 3 minggu setelah operasi katarak dan paling lambat dapat sampai 6 bulan setelah operasi katarak. ${ }^{9}$

Visus pada pasien adalah $5 / 60$, dengan kondisi visus 1 minggu setelah operasi adalah $5 / 7$ Berdasarkan clinically significant CME, CME didefinisikan jika terdapat visus 20/40 atau lebih buruk dan disertai dengan adanya ruang cystoid atau edema retina pada pemerikasaan slit lamp biomicroscopy dan pada pemeriksaan Fluoresence Angiography (FA) ditemukan adanya kebocoran kapiler perifovea.

Ruang cystoid yang terbentuk pada edema makula, secara patologis dapat terbentuk pada intraseluler atau ekstraseluler. Pada retina, makula merupakan daerah yang sering terjadi edema, hal ini disebabkan oleh anatomi makula yang unik yang ditandai dengan sel-sel yang mempunyai aktivitas metabolik yang tinggi dan terdapatnya daerah FAZ (Fovea Avascular Zone) ${ }^{1,10}$ Pembentukan ruang cystoid pada CME disebabkan oleh kebocoran kapiler perifovea sehingga memicu terjadinya penumpukan cairan di dalam lapisan pleksiform luar dan lapisan Henle. Ruangan yang terbentuk dalam lapisan Henle ini, berjalan ke lateral menjauhi sentral fovea. Pada area fovea, serat-serat lapisan pleksiform luar menunjukkan gambaran susunan yang longgar diikuti oleh akumulasi cairan yang berasal dari kebocoran kapiler-kapiler perifovea tersebut. ${ }^{6,11}$ Sediaan histolopatologi menunjukkan adanya dilatasi kapiler, cairan serosa di dalam lapisan pleksiform luar dan lapisan pleksiform dalam. Pada intrasitoplasma terdapat edema dari sel muller dan pada kasus yang berat dapat terjadi perubahan susunan fotoreseptor dan adanya cairan subretina. ${ }^{6,11}$

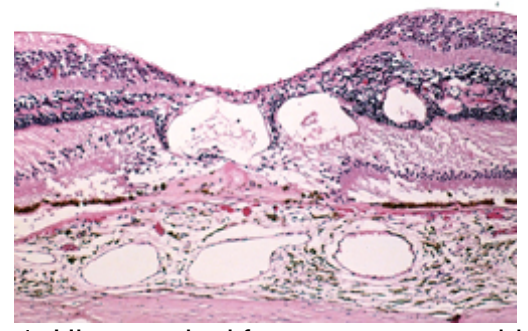

Gambar 1. Histopatologi fovea; ruang cystoid dengan transudat di dalam

Lapisan pleksiform luar dan lapisa inti luar. ${ }^{11}$

Beberapa penelitian juga menunjukkan ruang cystoid juga terbentuk pada lapisan nuklear luar, lapisan inti dalam, pleksiform dalam dan bahkan pada lapisan selsel ganglion. Sel-sel fotoreseptor rod dan cone pada area dibawah ruang juga dapat berkurang jumlahnya. ${ }^{6}$

Patogenesis pasti terjadinya Irvine-Gass Syndrome sampai saat ini masih belum diketahui, tetapi hasil akhir dari proses ini adalah terjadinya peningkatan permeabilitas kapiler perifovea dan ketidakstabilan vaskular intra okular. ${ }^{10,12}$

Pada kondisi normal, berbagai mekanisme yang dapat mencegah akumulasi cairan ekstraseluler dan cairan intra retina dan protein. Mekanisme ini mampu mempertahankan keseimbangan tekanan osmotik, tekanan hidrostatik, permeabilitas kapiler dan kebutuhan jaringan, sehingga kecepatan filtrasi kapiler sama dengan kecepatan pergerakan cairan dari jaringan retina ekstraseluler, oleh karena itu ruang interstisial retina dapat dijaga tetap dalam kondisi kering pada kondisi fisiologis. ${ }^{10}$

Akumulasi cairan dapat disebabkan oleh peningkatan influks cairan pada jaringan retina dengan clearance cairan melalui sel glia dan sel-sel RPE. Akumulasi cairan dapat disebabkan karena

1. Peningkatan tekanan hidrostatik, terjadi pada peningkatan aliran darah retina dan vasodilatasi.

2. Keseimbangan osmosis, terjadi pada hipoosmolaritas darah, vitreus dan hiperosmolaritas jaringan retina.

Penurunan clearance cairan melalui sel-sel glia dan sel-sel RPE dapat terjadi jika kondisi inflamasi mengganggu keseimbangan transpor osmotik, atau influk cairan melalui Blood-Retinal Barrier (BRB) melebihi kapasitas clearance sel. ${ }^{10}$

Hipotesa tentang penyebab edema makula sampai saat ini terus berkembang, salah satunya adalah hipotesa tentang keterlibatan vitreus dalam menyebabkan edema makula melalui beberapa mekanisme. Salah satu teori yang terkenal dikemukakan oleh Schubert pada tahun 1989 dan disimpulkan oleh Bringmann pada tahun 2009. Seratserat vitreus yang melekat pada sel-sel muller pada lokasi melekatnya vitreoretina, memberikan gaya traksional terhadap sel-sel mengakibatkan hipertrofi , proliferasi dan kebocoran vascular. Adanya stres mekanis jangka panjang dari sel-sel muller dan sel astrocyte diinduksi oleh perlekatan serat vitreus merangsang pengeluaran faktor-faktor inflamasi seperti basic fibroblast growth factor (bFGF), menginduksi inflamasi lokal dan rusaknya $B R B$ yang mengakibatkan kebocoran pembuluh darah dan edema makula. Traksi Vitreo retina (Vitreo Macular Traction/VMT) juga memberikan gaya pada tingkat RPE yang menyebabkan perubahan morfologis RPE. VMT juga dapat menginduksi lepasnya RPE atau robekan RPE. Adanya traksi pada makula atau pada RPE tidak hanya menginduksi inflamasi lokal tetapi juga meningkatkan Vascular Endothelial Growth Factor (VEGF) lokal dan selanjutnya terjadi pembentukan edema makula. Traksi secara mekanis juga dapat menyebabkan edema makula dengan adanya distorsi pembuluh darah di sekitar intra retina, mengakibatkan kebocoran yang merupakan akibat gangguan mikrosirkulasi makula dengan menurunnya aliran darah kapiler dan kehilangan perlengketan antara RPE dan pompa RPE. ${ }^{10}$

Teori inflamasi intra okular merupakan teori yang paling berkembang dalam menjelaskan terjadinya Irvine - Gass Syndrome. Operasi intra okular mencetuskan akumulasi makrofag dan netrofil 
yang diaktifkan oleh mediator inflamasi diantaranya cyclooxygenase, dan metabolit lipooxygenase, agenagen proteolitik. ${ }^{1,6}$ Pada jalur prostaglandin, inflamasi menyebabkan enzim phospholipase mengeluarkan asam arachidonat dari dinding sel. Selanjutnya cyclooxygenase merubah asam arachidonat menjadi prostaglandin. Cytokines seperti interferon $\mathrm{Y}$, interleukin-2, dan tumor nekrosis fator a juga berperan dalam menginduksi produksi cyclooxygenase. ${ }^{1,6,13}$

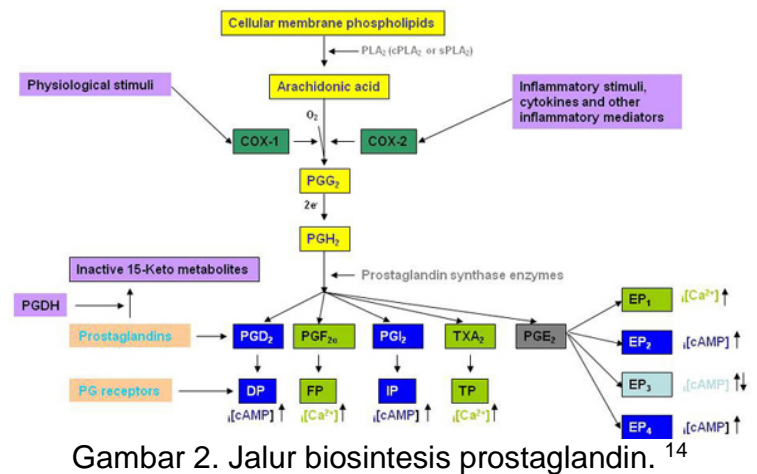

Prostaglandin dan mediator inflamasi ini kemudian diyakini berdifusi melalui vitreus menuju retina yang mengakibatkankan terganggunya $B R B$ yang memicu terjadinya CME. ${ }^{9,13,15}$

$B R B$ berperan dalam membatasi pergerakan konstituen plasma memasuki retina dan menjaga homeostasis retina. Pecahnya BRB memicu peningkatan permeabilitas kapiler dari jaringan pembuluh darah perifovea dan mengakibatkan pembentukan kista dan akumulasi cairan intraselular maupun ekstraselular. Akumulasi cairan akan mengganggu fungsi sel dan konfigurasi retina. Sel-sel Muller diduga bekerja sebagai pompa metabolik, yang menjaga makula tetap kering. Akumulasi cairan pada lapisan pleksiform luar diduga merupakan fenomena akhir dan diikuti oleh pecahnya sel-sel muller. 9,13,15

Sampai saat ini masih belum jelas mengapa cairan yang merembes dari akumulasi kapiler perifovea pada daerah fovea meskipun agen-agen inflamasi terdistribusi masif melalui retina. Tidak adanya pembuluh darah pada daerah FAZ kombinasi dengan aktivitas metabolik yang tinggi pada daerah fovea dapat menjelaskan berkurangnya reabsorbsi cairan yang merembes pada daerah ini. Struktur Membrana Limitans Interna (ILM) yang tipis pada makula, menyebabkan difusi agen inflamasi yang lebih besar dibandingkan di tempat lain. 9,13,15

Faktor resiko pada kasus ini tidak diketahui, faktor sistemik seperti riwayat dibetes mellitus, hipertensi disangkal, begitu juga dengan riwayat kondisi intraokular seperti uveitis juga tidak diketahui. Faktor resiko lain pada pasien ini diduga adalah faktor usia, pada penelitian Rossetti tahun 2000 menunjukkan faktor peningkatan usia merupakan faktor resiko terjadinya Irvine-Gass Syndrome..$^{1,4}$

Kondisi Intra operatif juga dapat menjadi faktor resiko terjadinya Irvine Gass Syndrome. Percivall tahun 1998 melakukan penelitian tentang perkembangan $\mathrm{CME}$ setelah implantasi IOL menunjukkan insiden CME pada pasien dengan ruptur kapsul posterior sebesar $27 \%$, penelitian Rossetti tahun 2000 menunjukkan korelasi positif antara kehilangan vitreus selama operasi katarak dengan peningkatan insiden Pseudofakic CME. Inkarserasi Iris juga dapat merupakan faktor resiko tambahan, adanya fragmen lensa yang tersisa, serta kontak yang lama dengan cahaya mikroskop selama operasi ${ }^{1,4}$

Pada pasien ini dilakukan pemeriksaan OCT untuk mendeteksi adanya cairan pada ruang subretina dan menilai ketebalan makula. Pada pemeriksaan OCT, menunjukkan kumpuulan ruangan hyporeflektif di dalam retina, dengan penebalan makula dan hilangnya depresi fovea. Menurut Willpem dkk, perubahan ketebalan makula $\geq 40 \mu \mathrm{m}$ merupakan indeks OCT significant macular edema. Pemeriksaan OCT sama efektifnya dengan pemeriksaan Fluorescein Angiography (FA) yang merupakan gold standar dalam diagnosis CME .Saat ini para klinisi lebih menyukai pemeriksaan OCT dibandingkan dengan pemeriksaan FA karena pemeriksaan OCT bersifat non-invasif sehingga lebih mudah dilakukan. Oleh karena itu pemeriksaan OCT juga direkomendasikan tidak hanya untuk diagnosis tetapi juga sebagai monitoring pada pasien-pasien post operatif apalagi jika terdapat kecenderungan memburuknya visus setelah operasi. Penelitian oleh Blanco dkk menunjukkan pemeriksaan OCT merupakan metode yang baik untuk mendeteksi Pseudofakic CME subklinis maupun subklinis. ${ }^{1,8,9,16,17}$ Kebanyakan kasus Pseudofakic CME mengalami resolusi spontan, sehingga sampai saat ini pemberian profilaks untuk kasus ini masih dalam perdebatan dan belum ada terapi standar untuk mengobati CME yang terjadi post operasi katarak. Riwayat terapi post operasi ECCE pada pasien ini diberikan steroid topikal tanpa kombinasi dengan NSAIDs topikal. Obat-obat golongan steroid seperti prednisolon dan dexamethason bekerja menghambat aktivitas prostaglandin melalui inhibisi pembentukan prostaglandin dari asam arachidonat. Tetapi obat steroid ini mempunyai kerugian karena bersifat lipofobik sehingga kemampuannya mencapai organ target menjadi terbatas. Selain itu penggunaan kortikosteroid dapat meningkatkan Tekanan Intra Okular (TIO). ${ }^{4,9}$ Menurut penelitan oleh Schuefele , pemberian steroid topikal saja tidak mensupresi sintesis mediator-mediator inflamasi saja seperti prostaglandin, sehingga memungkinkan terjadi proses inflamasi post operatif. Penelitian terbaru menunjukkan keuntungan pemberian monoterapi NSAIDs sebagai profilaks. ${ }^{9}$

Pasien ini diberikan yaitu Noncort eye drop berisi Natrium diclofenak $1 \mathrm{mg}$. Natrium diclofenac merupakan golongan NSAIDs topikal yang bekerja menghambat cyclooxygenase yang merupakan bagian penting dalam biosintesa prostaglandin. Patogenesa terjadinya Irvine Gass syndrome diduga disebabkan karena terjadinya inflamasi dimana pada saat operasi intra okular mencetuskan akumulasi makrofag dan netrofil yang diaktifkan oleh mediator inflamasi diantaranya cyclooxygenase, dan metabolit lipooxygenase, agen-agen proteolitik. 


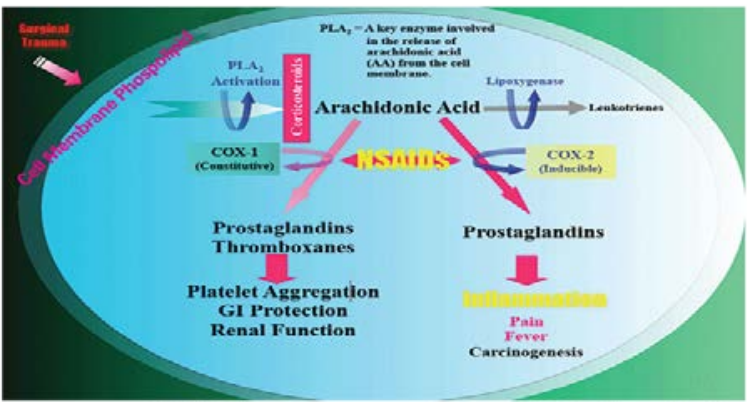

Gambar 3. Jalur asam arakhidonat pada proses inflamasi. ${ }^{13}$

Pemberian NSAID topikal ini merupakan modalitas terapi lini pertama yang direkomendasikan untuk kasus pseudofakic CME. ${ }^{17,18,19}$

Pada terapi awal dengan NSAIDs topikal ini , pasien memberikan respon yang cukup baik sehingga pada minggu pertama setelah terapi, terdapat perbaikan visus dan pada pemeriksaan OCT terdapat pengurangan dari ketebalan makula. Selain diberikan NSAIDs topikal, juga diberikan terapi oral dengan Carbonic anhidrase inhibitor. Carbonic Anhidrase Inhibitor (Acetazolamid) dapat mengurangi komponen edema karena kemampuannya dalam menstimulasi pompa RPE untuk mengurangi kelebihan cairan di makula, selain itu Carbonic Anhidrase Inhibitor juga dapat menginduksi oksidasi ruang subretina sehingga mengktkan absorbsi cairan dari retina melalui RPE menuju khoroid. Beberapa penelitian menunjukkan efek positif terhadap pemberian Acetazolamid pada kasus pseudofakic CME. 8,12, Pemberian Carbonic Anhidrase Inhibitor juga harus memperhatikan efek samping kehilangan potassium dan resiko sistemik sehingga obat ini dikombinasi dengan pemberian oral tablet Aspar K. Pada minggu ke 5 pemberian Carbonic anhidrase Inhibitor dihentikan, tetapi pada minggu ke 6

visus kembali menurun sampai $5 / 20$ dan pemeriksaan OCT terdapat peningkatan ketebalan makula $\pm 507 \mu \mathrm{m}$, sehingga pada minggu ke 7 , terapi Carbonic anhidrase kembali diberikan dan ditambah dengan kortikosteroid oral. Respon terapi cukup baik dimana terjadi perbaikan visus dan pada pemeriksaan OCT terdapat pengurangan ketebalan makula.

Pada beberapa kasus, CME tidak berespon terhadap pemberian terapi topikal atau terapi sistemik. Terapi kemudian dapat dilanjutkan dengan pemberian Kortikosteroid Periocular atau Intra okular Kortikosteroid yang paling sering digunakan pada terapi periokular dan intra okular adalah triamcinolone. Triamcinolone merupakan kortikosteroid yang bersifat long-acting dan larut dalam air. Obat ini diberikan secara injeksi pada daerah lantai orbita atau injeksi sub tenon, tetapi saat ini lebih sering diberikan secara intra vitreal karena lebih efektif dan dosis yang diberikan minimal. Walaupun demikian, pemberian obat ini juga mempunyai komplikasi baik oleh karena obat itu sendiri maupun karena prosedur injeksi. Efek samping kortikosteroid intravitreal diantaranya peningkatan Tekanan Intra Okular. ${ }^{4.20}$ Pemberian Anti VEGF seperti bevacizumab (avastin) baru-baru ini telah dipakai dalam pengobatan Pseudofakic CME. Mekanisme patofisiologi dari kerja obat ini masih belum jelas. Keuntungan dari obat anti VEGF dalam terapi Psedofakic CME saat ini masih dalam penelitian dan masih kontoversi. 1,4Terapi operasi diindikasikan jika secara klinis terjadi CME kronis dan tidak respon dengan terapi obat. Dalam hal ini dapat digunakan
Terapi Nd YAG laser dan vitrektomi untuk mengangkat perlengketan vitreus pada insisi katarak. 20,21,22

Pada pasien ini selain diberikan terapi untuk Irvine -Gass Syndrome, juga diberikan terapi obat anti glaukoma yaitu timol $0,5 \%$ untuk mata kiri. Pemberian terapi ini bertujuan untuk menurunkan tekanan intra okular (TIO) pada mata kiri yang telah didiagnosis sebagai Glaukoma absolut.

Prognosis Irvine-Gass Syndrome pada pasien ini cukup baik, hal ini dibuktikan dengan respon terapi yang cukup baik yang dimonitor dengan adanya perbaikan visus dan pemeriksaan OCT.

Sebagai rekomendasi untuk manajemen dan pencegahan Irvine- Gass Syndrome, sebaiknya sebelum operasi katarak dilakukan dilakukan pengelompokan pasien berdasarkan faktor resiko, pemberian profilaks NSAIDs topikal dan mempertimbangkan kondisi intra operatif pasien. ${ }^{4}$

\section{KESIMPULAN}

Pseudofakic CME atau disebut juga Irvine- Gass Syndrome merupakan salah satu penyebab tersering kehilangan visus pada pasien post operasi Katarak. Pada Pseudofakic CME terjadi akumulasi cairan pada ruang subretina akibat adanya terjadinya peningkatan permeabilitas kapiler perifovea dan ketidakstabilan vaskular intra okular yang merupakan konsekuensi akibat terjadinya gangguan atau kerusakan pada Blood Retinal Barrier. Patogenesa terjadinya Pseudofakic CME masih belum diketahui tetapi teori inflamasi intra okular merupakan teori yang paling berkembang dalam menjelaskan terjadinya Irvinne Gass Syndrome. Pada Kasus ini Pseudofakic CME terjadi \pm 12 minggu setelah operasi katarak dan diagnosis ditegakkkan berdasarkan gejala klinis serta pemeriksaan OCT. Pada Follow up terdapat respon terapi yang cukup baik dengan kombinasi NSAIDs topikal dan kortikosteroid oral serta diberikan juga Carbonic Anhidrase Inhibitor dengan pengawasan terhadap efek samping dan resiko sistemik. Rekomendasi untuk manajemen dan pencegahan Irvine- Gass Syndrome, sebaiknya sebelum operasi katarak dilakukan dilakukan pengelompokan pasien berdasarkan faktor resiko, pemberian profilaks NSAIDs topikal dan mempertimbangkan kondisi intra operatif pasien.

\section{DAFTAR KEPUSTAKAAN}

1. Silimbaris KM,Tsika C,Diakonis V, Karavitaki A,Pallikaris I. Macular Edema and Cataract Surgery. In Cataract Surgery. University of Crete Medical School. Greece.2010;323-336.

2. Ouyang Y, Keane PA,Sadda RS, Walsh CA. Detection of Cystoid Macular Edema with ThreeDimensional Optical Coherence Tomography versus Fluorescein Angiography. In Journal of The Association for Research in Vision and Opthalmology.Los Angeles.2010;1-10

3. Dinc AU,Tatlipinar S, Yenerel M, Gorgun E,Ciftci F. Fundus Autoflorescence in Cystoid Macular Edema: Can it Be an Ancillary Test?.In Journal Ret-Vit $2010.18^{\text {th }}$ edition. Yeditepe University Eye Hospital.Turkey.2010;12-17.

4. Lobo C. Pseudophakic Cystoid Macular Edema. In Journal Karger.Portugal.2011;1-5

5. Chalam KV,Khetpal V, Patel JC. Spectral Domain Optical Coherence Tomography Documented Rapid Resolution of Pseudophakic Cystoid Macular 
Edema with Topical Difluprednate. In Clinical Opthalmology. Dovepress. Florida. 2012;155-158

6. Narayanan R,Kuppermann BD. Macular Causes of Poor Postoperative Vision: Cystoid Macular Edema, Epiretinal Fibrosis, and Age-Related Macular Degeneration. In Clinical Opthalmology A systematic Approach. Elsevier Saunders. London. 2011.661-663.

7. Marthinez MR, Ophir A. Pseudophakic Cystoid Macular Edema Associated with Extrafoveal Vitreoretinal Traction. In The Open Opthalmology Journal. Volume V. 2011.35-41.diakses dari http://creativecommons.org/licenses/by-nc.

8. Walter KA. .Prevention of Pseudofakic Cystoid Macular Edema. In Topics In Ocular Antiinflammatories. CME publication. Florida;2012;1-5.

9. Scheufele T, Heier JS. Pseudophakic Cystoid Macular Edema. In Cataract \& Refractive Surgery Today. 2005; 54-56

10. Konstantinidis L,Wolfensberger TJ. Cystoid Macular Edema and Vitreomacular Traction. In Retina. 5 Edition. Philadhelphia.2012:1979-1983.

11. Lally DR, Shah CP. Pseudophakic Cystoid Macular Edema. In Review of Opthalmology diakses dari http://www.revophth.com/content/d/retinal insider/c |46967|

12. Skuta L, Cantor LB, Weiss SJ. Complications Of Cataract Surgery.In Lens and Cataract. American Academy Of Ophthalmology. San Fransisco. 2011;193-195.

13. Jamal KN,Goldenberg DT. Causes and Treatment of Pseudophakic CME.In Review Of Optalmology.2009. Diakses dari http://www.revophth.com/content/d/retinal insider/i/ $1217 / \mathrm{c} / 22919 /$

14. Gerritsen ME.Physiological and Pathophysiological roles of eicosanoid. In Cardiovascular Research. Diakses dari http://cardiovascres.oxfordjournals.org/

15. Skuta L, Cantor LB, Weiss SJ. Retinal Vascular Disease.In Retina and Vitreous. American Academy of Ophthalmology. San Fransisco. 2011:167-169.

16. Holz FG,Spaide RF. Clinical Use of OCT. In Medical Retina.Springer. Philadhephia.2009.15-17.

17. Blanco TF.Moreno R. Pseudophakic Cystoid Macular Edema. Assesment With Optical Coherence Tomography. In Arch Soc Esp Oftlmol. Spanyol.2006;147-152.

18. Hariprasad SM., Akduman L, Clever JA. Treatment of Cystoid Macular Edema With The New Generation NSAID nepafenac $0.1 \%$. In Clinical Opthalmology. Dove medical Press. Chicago.2009;147-154.

19. Sivaprasad S, Bunce C, Wormald. Non-Steroidal Anti Inflamatory Agents for Cystoid Macular Oedema Following Cataract Surgery: A Systematic Review. In Journal Opthalmology. Diakses dari www.bjophthalmol.com .2005;1420-1422.

20. Clark L.Intraocular Steroids For Cystoid Macular Edema. In Advance Ocular Care. Columbia.2010;36-38.

21. Telander DG. Psedofakic (Irvine -Gass) Macular Edema. Diakses dari http://emedicne.medscape.com. 2012;1-6.

22. Kiernan DF. Controversies In The Management of Irvinne Gass Syndrome. In Practical Retina;
Opthalmic Surgery, Laser \& Imaging Retina Volume 44. Healio.Chicago. 2013.522-527. 